\title{
Development of a Twenty-Two Point Multichannel Temperature Data Logger Specially Customized and Coupled to a 160Wpeak Hybrid Photovoltaic/Thermal (PV/T) Flat Plate Solar Air Heater ${ }^{\dagger}$
}

\author{
A. I. Obi ${ }^{1, *}$, O. C. Iloeje ${ }^{1}$, C. O. Anyaoha ${ }^{1}$ and O. Ojike ${ }^{2}$ \\ 1 Department of Mechanical Engineering, University of Nigeria, Nsukka, Nigeria \\ 2 Department of Agricultural and Bioresource Engineering, University of Nigeria, Nsukka, Nigeria \\ * Correspondence: amarachukwu.obi@unn.edu.ng; Tel.: +234-8037326685; https://orcid.org/0000-0001- \\ 8640-3721 \\ + Presented at the 7th International Electronic Conference on Sensors and Applications, 15-30 November \\ 2020; Available online: https://ecsa-7.sciforum.net/.
}

Published: 15 November 2020

\begin{abstract}
A low cost multichannel temperature data logger was designed and fabricated in this study. The design was done using Max6675 temperature sensors and linear monolithic (LMs) temperature sensors. This data logger is an electronic device that records data over time based on microcontroller. The utilization of data logger in this work is to accomplish the task of monitoring the temperature measurement of the 160 Wpeak hybrid photovoltaic/thermal $(\mathrm{PV} / \mathrm{T})$ flat plate solar air heater. This data logger is just customized for this equipment - the hybrid photovoltaic/thermal solar air heater. The developed prototype was internally or externally powered and has a retrievable memory card module. The sensor's response time was observed to be one minute leading to a time series analysis. It was observed from the graphical plots that the temperature patterns were in consonance with the solar radiation patterns. The trend of the temperature flow pattern measured from the hybrid photovoltaic/thermal (PV/T) flat plate solar air heater was in consonance with the solar radiation flow pattern. This indicates that the peaks of the temperature plots fall at the peaks of the plots of solar radiation.
\end{abstract}

Keywords: data logger; temperature; sensors; hybrid photovoltaic/thermal; flat plate; solar air heater

\section{Introduction}

Typically, data loggers are small, stand-alone, battery-powered devices that are equipped with a microprocessor, memory for data storage and sensors [1]. In this paper, we present a portable and rugged data acquisition module that is designed to monitor the temperature of the hybrid photovoltaic/thermal flat plate solar air heater. Understanding the temperature flow/state during a certain time is needed in various systems. Temperature level can affect various types of measurement recorded, hence, temperature must be maintained within certain limits to achieve repeatable results, reduce the cost of tedious correctness requirements [3]. With the desired temperature requirements in every field, it is becoming more and more important for measuring and controlling of temperature [3]. This leads to the problem of finding suitable measurement devices with the least hassles in obtaining temperature data considering that most measurements are carried out for a long periods to cater for changing thermal patterns over different times/seasons [3]. Most low-cost temperature 
measuring devices are hand-held and are not suitable for such work whereas some other temperature loggers are quite expensive.

Multipoint data logging is a method of automatic data capture (using digital technologies such as advanced microprocessors, solid state sensors and fully featured software, which maximize accuracy) in which values from a sensor are recorded and stored in a regular intervals [2,3]; in this case linear time series of one minute. Thus, this temperature logger is a portable measurement device that is capable of autonomously record temperatures over a time series of $1 \mathrm{~min}$. These sensors are also physical phenomena that are stimuli into electronic signals [3]. These electronic signals such as temperatures in this work are then converted into digital data that can be retrieved, and used as the need arises. As there is no moving part to wear out and with powerful software compensation, data loggers can deliver greater accuracy over larger periods of time $[3,4]$. The objectives of this work are to develop a portable low cost temperature logger using max6675 and LM35 for the measurement of temperatures of the PV/T flat plate solar air heater and its evaluation. The need for this design arose as a result of the fact that most temperature loggers are beyond the reach of most researchers in developing countries due to the high cost of these systems and the difficulty in accessing funds prevalent in these regions.

\section{System Design}

The data logger prototype was developed based on a microcontroller, battery powered, and equipped with internal memory module for data Storage, Real Time Clock (RTC) and sensors $[5,7]$. The system developed has a "low power Consumption", "low cost", portable and can be easily used to measure temperatures in the PV/T flat plate solar air heater system. Figure 1 shows the block diagram of the temperature data logger. Figure 2 shows the temperature data logger software flowchart. The logger starts and initializes, communicates, displays and memory card checked and displays memory card ok. Microcontroller unit (mCU) detects the timer/tick every $1 \mathrm{~s}$ to check RTC time stamp [7]. For example, if the timestamp was set to $1 \mathrm{~min}$, then $\mathrm{mCU}$ will record temperature for every $1 \mathrm{~min}$ into memory.

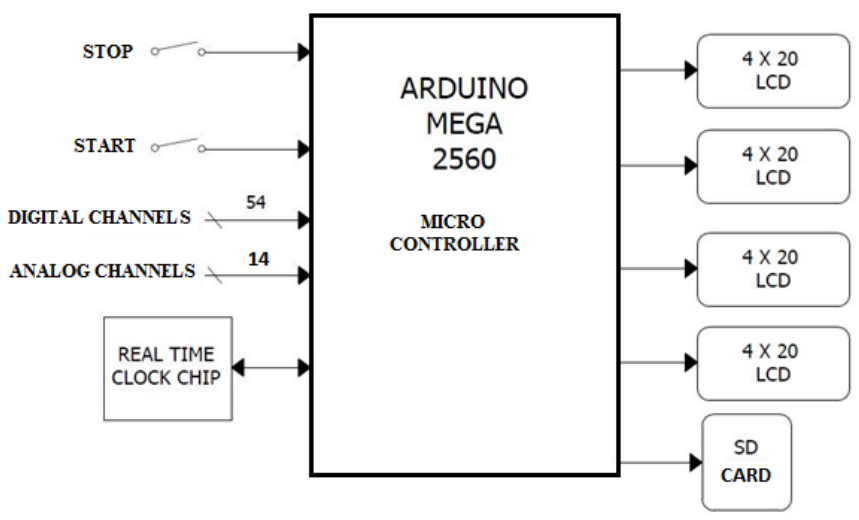

Figure 1. The Block diagram of the data logger. 


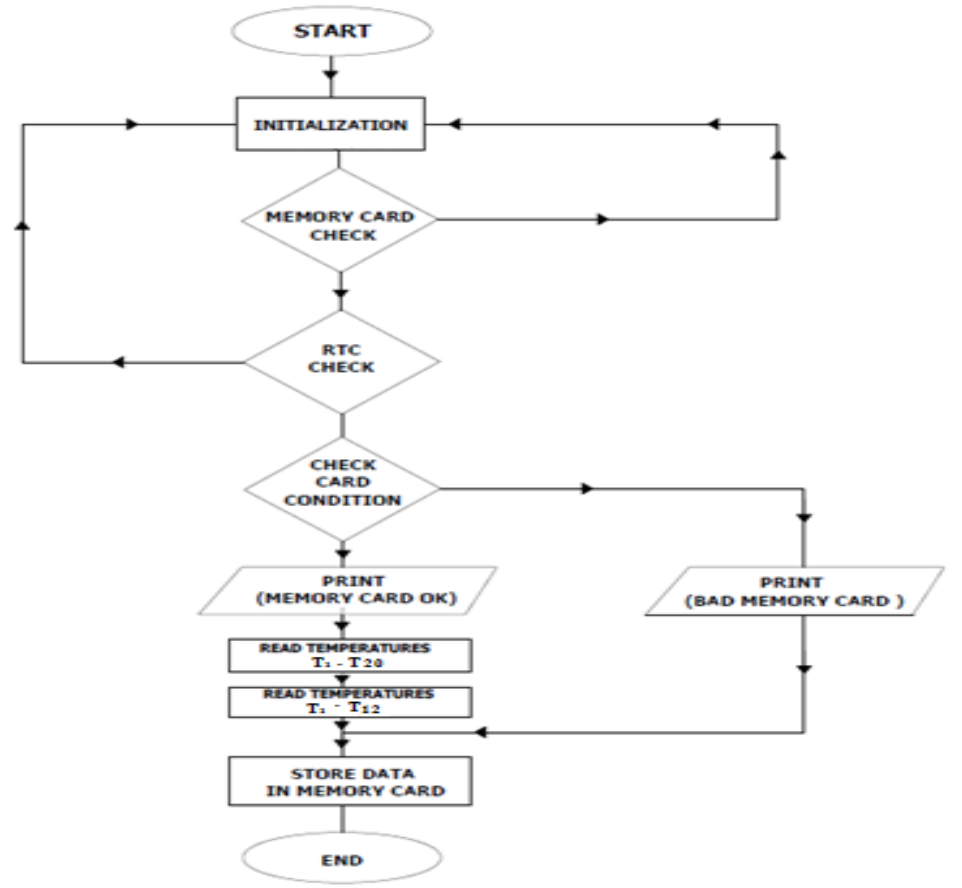

Figure 2. The data logger software flowchart.

\section{Materials and Methods}

The two most important parts of the system are the sensing elements and the data processing elements. The data processing element used in this work is arduino, a microcontroller. A microcontroller is a small computer on a single integrated circuit containing a processor, memory, and programmable input/output peripherals [6,11]. The Arduino Mega is a microcontroller board based on the ATmega 2560 [datasheet]. It has 54 digital input/output pins (of which 14 can be used as Pulse-width modulation, PWM Output). A $16 \mathrm{MHz}$ crystal oscillator, a Universal Serial Bus (USB) connection, a power jack, an In-Circuit Serial Programming (ICSP) header and a reset button. It contains everything needed to support the microcontroller; simply connect it to a computer with a USB cable or power it with an AC-to-DC adapter or battery to get started [7,12]. It is programmed with the Arduino software. Figure 3 shows the electronic circuit diagram of the power logger.

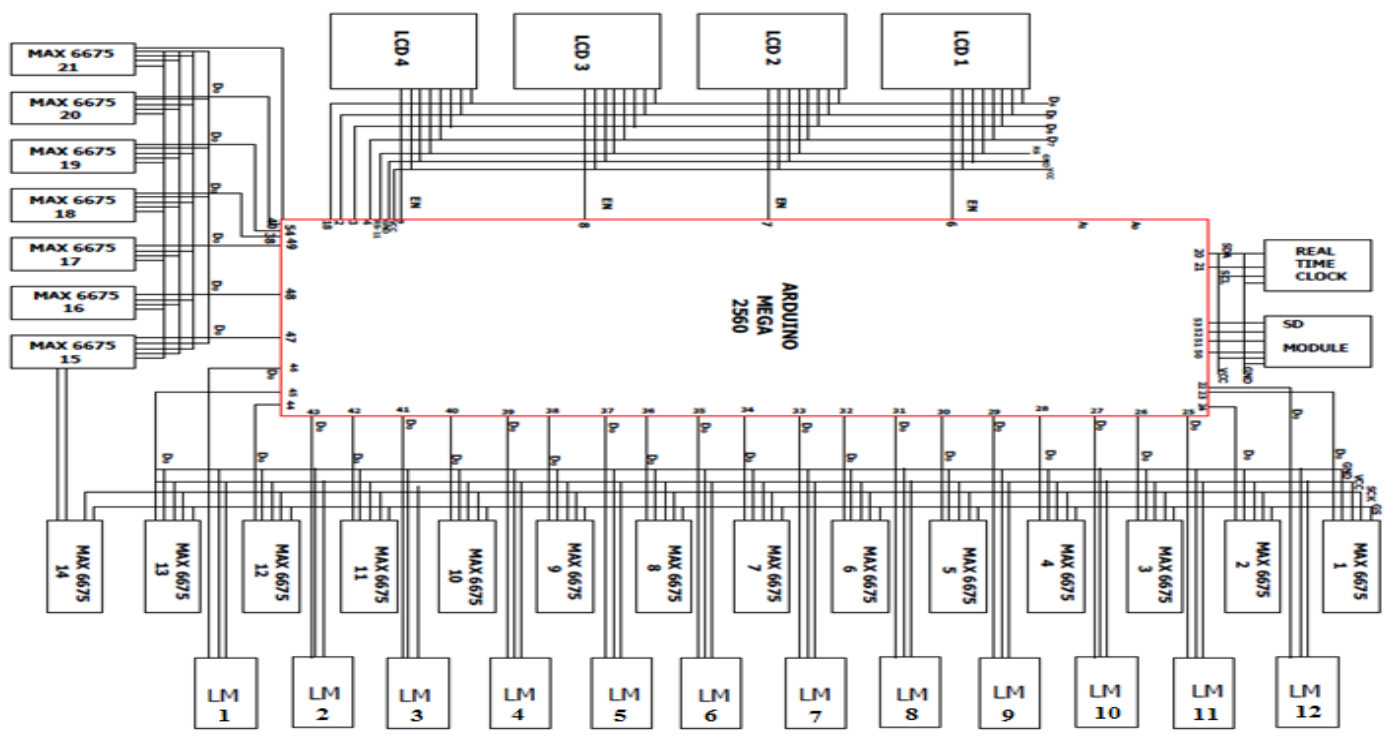

Figure 3. The Electronic Circuit Diagram of the Data Logger. 


\section{Field Testing Results}

Data logger prototype was installed and tested oin the field for the duration of six months for a particular research work at University of Nigeria, Nsukka, Nigeria [15]. The installation connection diagram and the hybrid PV/T flat plate solar air heater being monitored are shown in Figures 4 and 5. The generated results processes from the temperature data logger are shown in Figures 7-10.

Figure 7 is the graph of temperatures (temperatures at the front or top of the PV module, the temperatures at the back of the PV module, the temperatures of air flow in the first channel of the air heater, the temperatures of the second flat plate-the black painted aluminum sheet, the temperatures of the air flow in the second channel and finally, the temperatures of the bottom plate of the air heater (black painted) against time interval [15]. And in this work, the time interval is regarded as time series hence, the temperature logger takes reading at every $1 \mathrm{~min}$. From the graph in Figures 7 and 9 as the temperatures fluctuated the solar radiation fluctuated as well. Let's take a look at Figure 8 . We brought out one temperature point called temperature $\mathrm{T}_{1}$ which is one of the temperatures at the back of the PV module (the flat plate solar collectors of the hybrid PV/T flat plate solar air heater. This one temperature point was compared with the solar radiation. The solar radiation was measured with a standard solar radiation logger known as TES 1333R Datalogging Solar Power Meter. Of course if you look at the comparison between the temperature point and the solar radiation in Figure 8, you will find out that they compared well though, there might be some errors due to human or the instrument (probably settings on the meter et cetera). From Figure 8 the positive and negative turnings of the temperature point almost compared well with the insolation. Figure 10 behaved alike also. Showing that my locally made temperature data logger could also compare well with the standard logger such as TES 1333R Datalogging Solar Power Meter. In my next edition of publication, it was realized that the temperature ambient point compared well with the standard temperature-humidity data logger. From this work it can be known that the trend of temperature flow pattern is the same as the solar radiation trend. However some sharp decrease in temperature was sometimes as a result of shading in weather conditions [8,9]. The trend of temperature flow in ${ }^{\circ} \mathrm{C}$ depend on the trend of solar radiation in $\mathrm{W} / \mathrm{m}^{2}$. From the above, it shows that the operating module temperatures and other temperature points in the system are so much dependent on solar radiation [10].

From [10], we state that the main factors that determine the output power of the hybrid PV/T flat plate solar air heater system are: (i) hybrid PV/T system conversion efficiency, (ii) radiation intensity, and (iii) temperature of solar cells. The hybrid PV/T system efficiency means the output power of the hybrid PV/T per unit radiation of solar cells. The hybrid PV/T system efficiency is dependent on two factors namely solar radiation and temperature. Every degree centigrade rise in temperature above the reference temperature the silicon cell power output decreases by about $0.5 \%$ approximately $[13,14]$. Tables A1-A4 below are the specifications for the module, charge controller, battery and inverter [15] shown in the appendix.

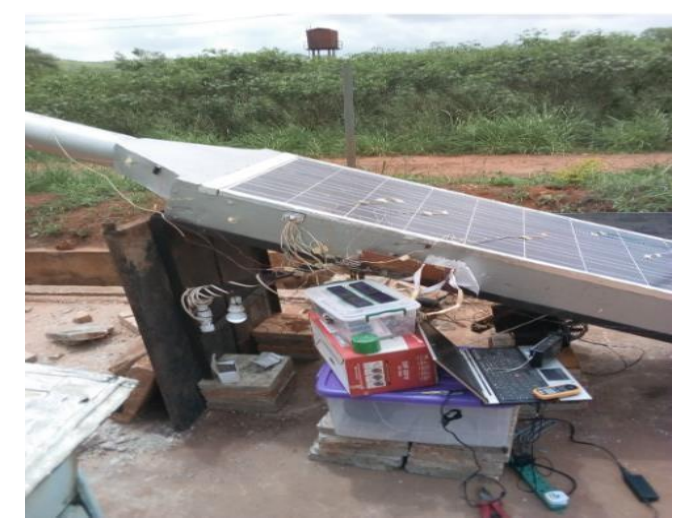

Figure 4. Hybrid PV/T air heater and the logger. 


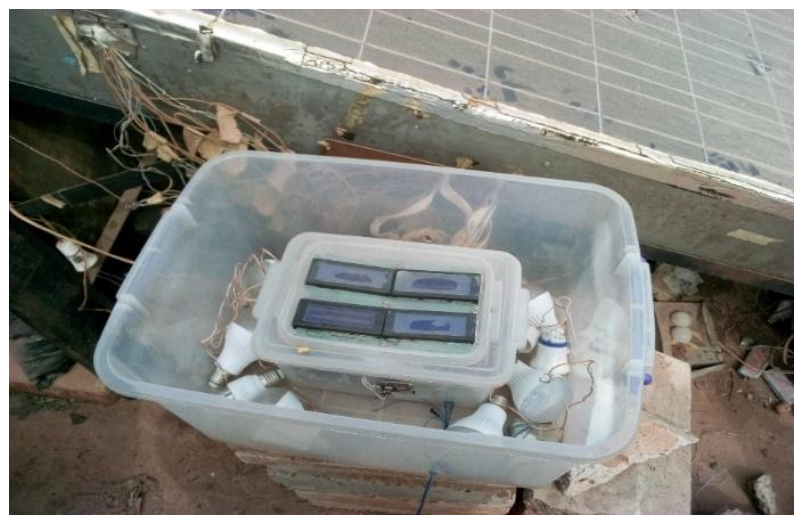

Figure 5. The temperature data logger an aerial view.

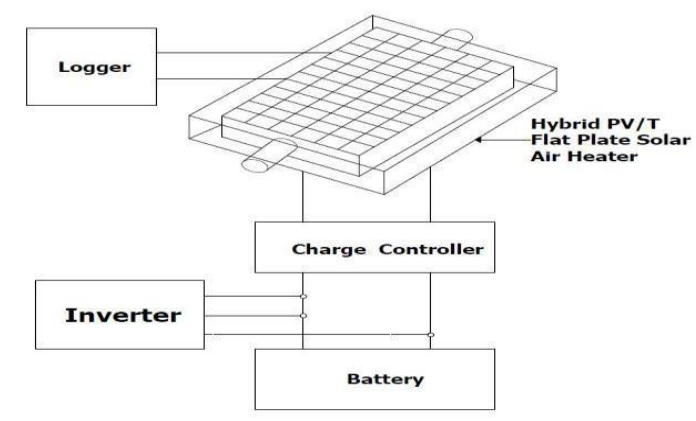

Figure 6. The schematic diagram of the hybrid PV/T air heater \& logger.

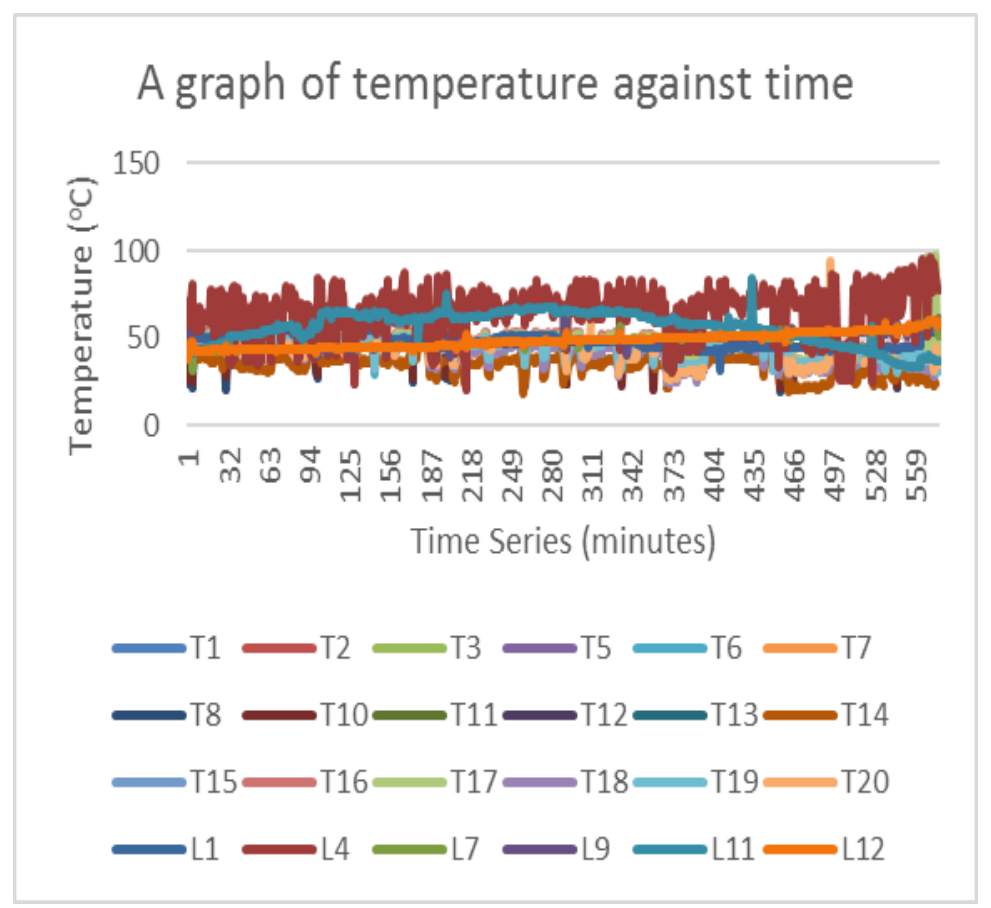

Figure 7. Various temperature points in the hybrid PV/T flat plate solar air Heater. 17/01/2019 measurement. 


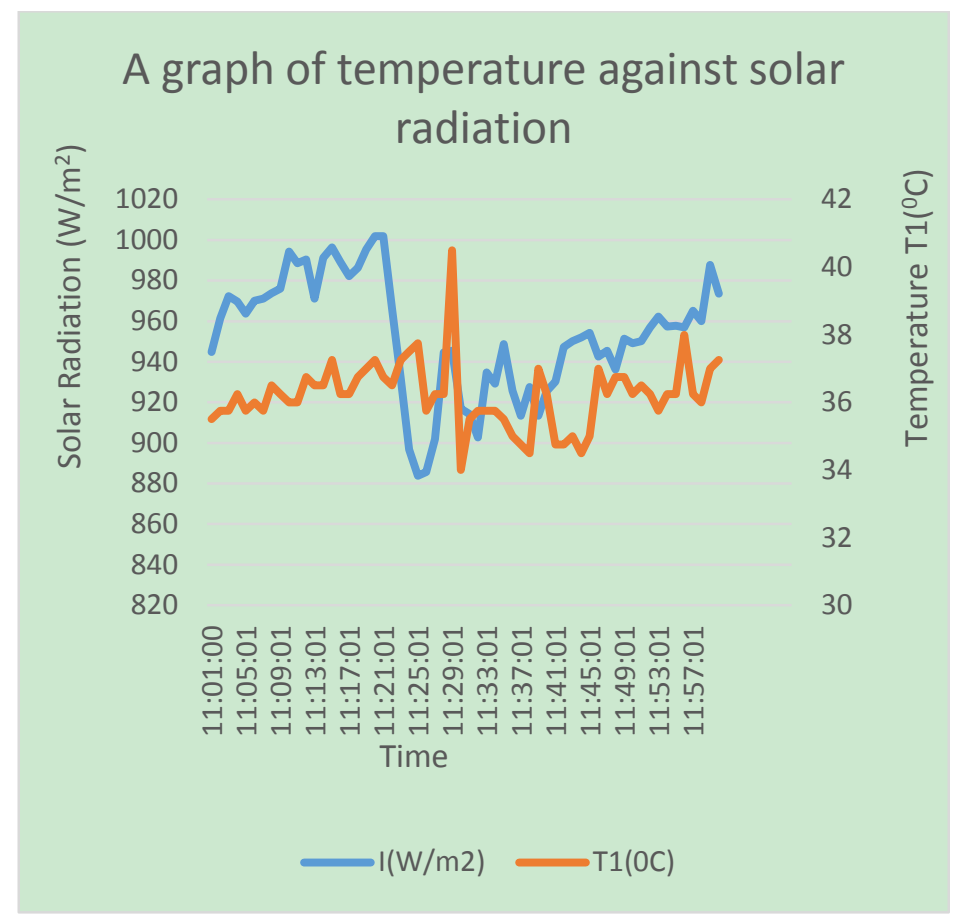

Figure 8. A comparison of temperature and insolation. 17/01/2019 measurements.

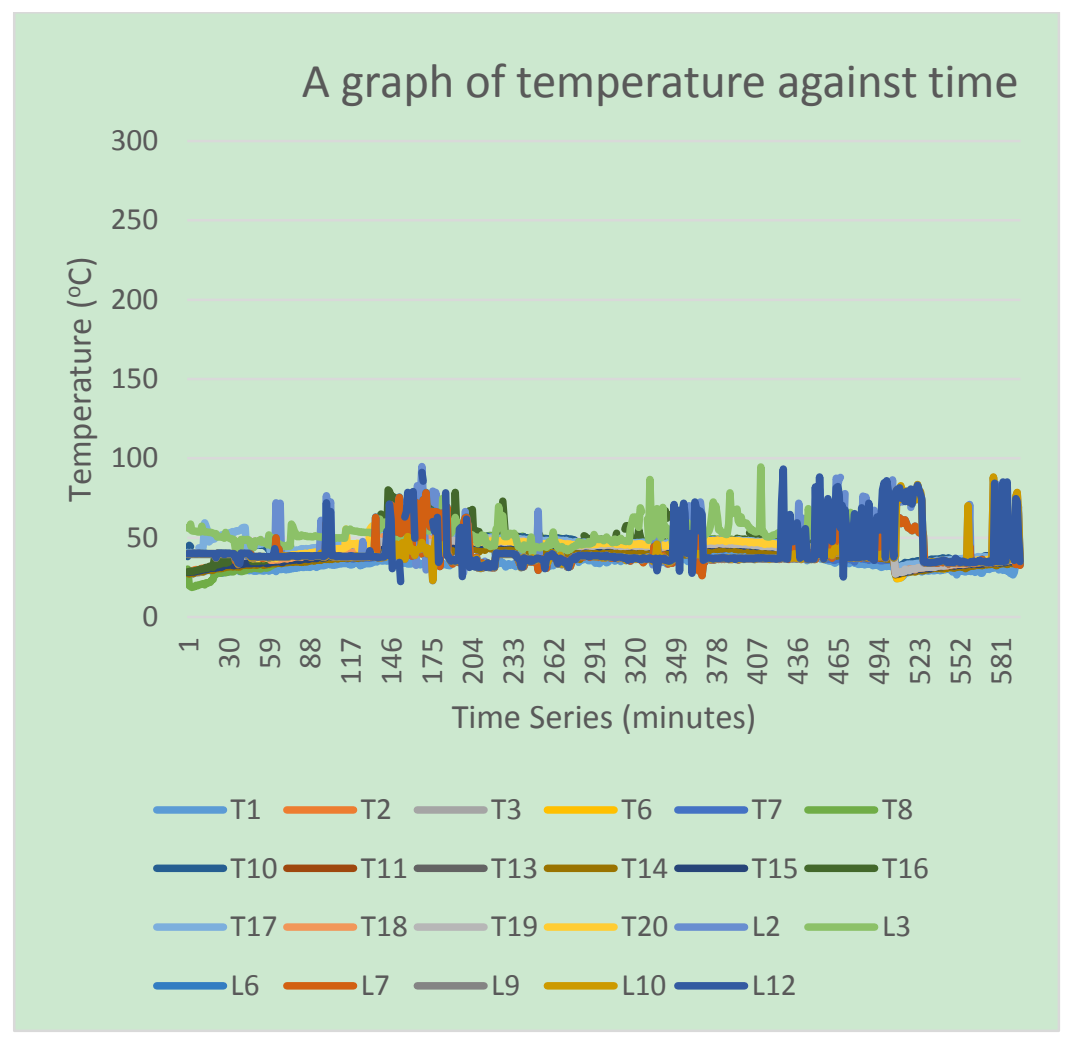

Figure 9. Various temperature points in the hybrid PV/T flat plate solar air Heater. 17/01/2019 measurement. 


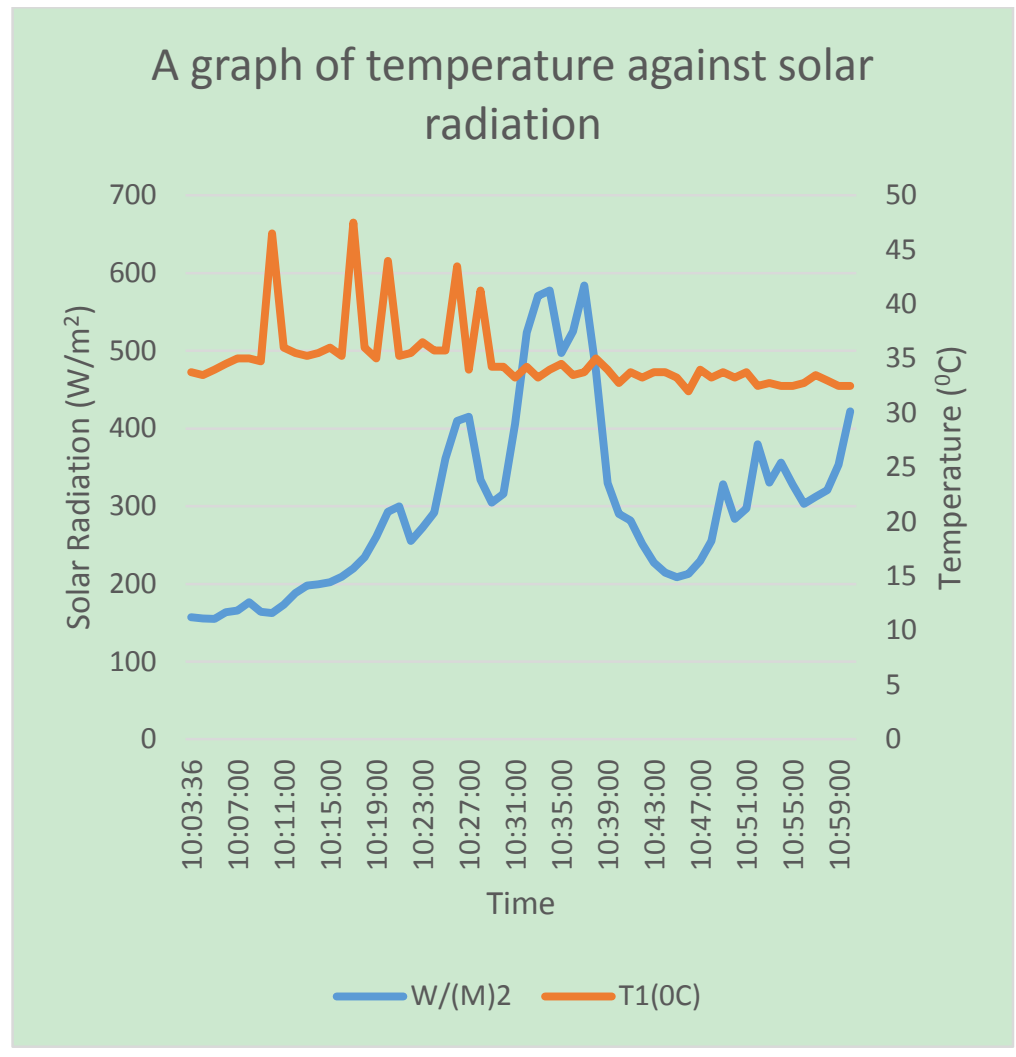

Figure 10. A comparison of in the hybrid PV/T flat plate solar air Heater. 17/01/2019 measurement.

\section{Conclusions}

The data logger was developed and tested. It showed good picture of the temperature flow patterns in sympathy with insolation and compared well with standard loggers. The temperature data logger prototype was developed based on ATmega 2560 microcontroller. The total power consumption measured of the data logger on active state was about $\approx 8.5 \mathrm{~W}\{0.037 \mathrm{~A} \mathrm{(ac)}$ at $225 \mathrm{~V}(\mathrm{ac})\}$. For further development, the logger can be equipped with ability to check MPPT functions of the solar PV module and also to measure alternating current of electrical systems.

\section{Appendix A}

Table A1. Solar cell module specifications.

\begin{tabular}{cc}
\hline Number of module & 1 \\
\hline Nominal Voltage & 12 \\
\hline Maximum Power & $160 \mathrm{WP}$ \\
\hline Voltage Max (Pmax) & $17.5 \mathrm{~V}$ \\
\hline I max P(max) & 9.15 ampere \\
\hline Short Circuit Current, Isc & 10.07 ampere \\
\hline Open Circuit Voltage & $21.5 \mathrm{~V}$ \\
\hline Diode & Blocking \& Bypass \\
\hline
\end{tabular}


Table A2. Charge controller specifications.

\begin{tabular}{cc}
\hline Charging Method & PWM (Pulse Width Modulation) \\
\hline Solar input capacity & 20 ampere \\
\hline Load capacity & 20 ampere \\
\hline Regulator Voltage & $14.2 \mathrm{~V}$ \\
\hline Overload Capacity & 20 ampere \\
\hline Self-Consumption & $10 \mathrm{~mA}$ \\
\hline Operating Temperature & $-35{ }^{\circ} \mathrm{C}-+50^{\circ} \mathrm{C}$ \\
\hline
\end{tabular}

Table A3. Battery specifications.

\begin{tabular}{cc}
\hline Acid & $\mathrm{H}_{2} \mathrm{SO}_{4}$ \\
\hline Capacity & $100 \mathrm{Ah}$ \\
\hline Nominal Voltage & 12 volt \\
\hline
\end{tabular}

Table A4. Inverter specifications.

\begin{tabular}{cc}
\hline Output Waveform & Modified Sine Wave \\
\hline Output Power & 1000 watt \\
\hline Output Voltage & 220 VAC \\
\hline
\end{tabular}

\section{References}

1. Daly, G.M.; Flye, H.J. The Use of Low-Cost Data Logger in Monitoring Building System Performance. Data Acquisition Series Part 5. Energy Eng. 2000, 97, 33-42.

2. Abrar, M.D.; Patil, R.R. Multipoint Temperature Data Logger and Display on PC through Zigbee using PSoC. Int. J. Adv. Res. Comput. Commun. Eng. 2013, 2, 3382-3391.

3. Ojike, O.; Mbajiorgu, C.C.; Anoliefo, E.; Okonkwo, W.I. Design and Analysis of a Multipoint Temperature DataLogger. Niger. J. Technol. (NIJOTECH) 2016, 35, 458-464, doi:10.4314/njt.v35i2.30.

4. Badhiye, S.S.; Chatur, P.N.; Wakode, B.V. Data Logger System: A Survey. Int. J. Comput. Technol. Electron. Eng. 2008, 24-26.

5. Aneja, B.; Singh, S.; Chandna, U.; Maheshwari, V. Review of Temperature Measurement and Control. Int. J. Electr. Electron. Eng. 2011, 3, 29-37.

6. Arduino cc. "Arduino and Genuino Products Overview".

7. Purwadi, A.; Haroen, Y.; Ali, F.Y.; Heryana, N.; Nurafiat, D.; Assegaf, A. Prototype Development of a Low Cost Data Logger for PV Based LED Street Lighting System. In Proceedings of the 2011 International Conference on Electrical Engineering and Informatics, Bandung, Indonesia, 17-19 July 2011.

8. Guerrero, J.; Munoz, Y.; Ibanez, F.; Ospino, A. Analysis of Mismatch and Shading Effects in a Photovoltaic Array Using Different Tecnologies. In IOP Conference Series: Material Science and Engineering; IOP Publishing: Bristol, UK, 2014.

9. Dolara, A.; Lazaroiu, G.C.; Leva, S.; Manzolini, G. Experimental Investigation of Partial Shading Scenarios on Photovoltaic (PV) Modules. Energy 2013, 55, 466-475.

10. Duffie, J.A.; Beckman, W.A. Solar Engineering of Thermal Processes, 3rd ed.; John Wiley and Sons, Inc.: Hoboken, NJ, USA, 2006.

11. Obi, A.I.; Iloeje, O.C.; Anyaoha, C.O. Design, Fabrication and Testing of Prototype Microcontroller Based Multipurpose Multichannel Electric Logger. In Proceedings of the Second NIEEE Nsukka Chapter Conference on Sustainable Infrastructure Development in Developing Nations, 26-29 February 2020; Volume 1, No. 2, pp. 44-50.

12. Obi, A.I.; Udosen, A.N.; Anyaoha, C.O. Design, Construction and Testing of Multipoint Humidity, Temperature Data Logger. In Proceedings of the 1st International Multidisciplinary Conference on Technology, December 2019; Volume 1, No. 1, pp. 101-10950.

13. Cha, S.T.; Jeon, D.H.; Bae, I.S.; Lee, R.; Kim, J.O. Reliability evaluation of distribution system connected photovoltaic generation considering weather effects. In Proceedings of the 8th International Conference on Probabilistic Methods Applied to Power System, Iowa State University, Ames, IA, USA, 2004; pp. 451-456. 
14. Patel, M.R. Wind and Solar Power Systems: Design, Analysis and Operation, 2nd ed.; Taylor \& Francis: Boca Raton, FL, USA, 2006.

15. Obi, A.I. Performance Analysis of Hybrid Photovoltaic/Thermal Flat Plate Solar Air Heater with Double Layered Flow. Unpbl. Ph.D. Thesis, Department of Mechanical Engineering, University of Nigeria, Nsukka, Nigeria, in view.

Publisher's Note: MDPI stays neutral with regard to jurisdictional claims in published maps and institutional affiliations.

(C) 2020 by the authors. Submitted for possible open access publication under the terms and conditions of the Creative Commons Attribution (CC BY) license (http://creativecommons.org/licenses/by/4.0/). 